\title{
Cyclin-Dependent Kinase 4 Inhibitor B
}

National Cancer Institute

\section{Source}

National Cancer Institute. Cyclin-Dependent Kinase 4 Inhibitor B. NCI Thesaurus. Code C17784.

Cyclin-dependent kinase 4 inhibitor B (138 aa, $15 \mathrm{kDa})$ is encoded by the human CDKN2B gene. This protein plays a role in the modulation of cell cycle progression. 